\title{
An Uncommon Case of Pediatric Neurobrucellosis Associated with Intracranial Hypertension
}

\author{
Xenophon Sinopidis, ${ }^{1}$ Joseph Kaleyias, ${ }^{2}$ Konstantina Mitropoulou, ${ }^{2}$ Maria Triga, ${ }^{2}$ \\ Sanjeev V. Kothare, ${ }^{3}$ and Stefanos Mantagos $^{2}$ \\ ${ }^{1}$ Department of Pediatric Surgery, Patras University Hospital, University of Patras Medical School, Patras 26504, Greece \\ ${ }^{2}$ Department of Pediatrics, Patras University Hospital, University of Patras Medical School, Patras 26504, Greece \\ ${ }^{3}$ Department of Neurology, Boston Children's Hospital, Harvard Medical School, Boston, MA 02115, USA
}

Correspondence should be addressed to Xenophon Sinopidis, xsinopid@upatras.gr

Received 26 March 2012; Accepted 21 June 2012

Academic Editors: V. Misra and S. Talhari

Copyright (c) 2012 Xenophon Sinopidis et al. This is an open access article distributed under the Creative Commons Attribution License, which permits unrestricted use, distribution, and reproduction in any medium, provided the original work is properly cited.

We present the case of a 4-year-old boy who was admitted to hospital with intracranial hypertension, headache, diplopia, papilledema, and a normal brain MRI. Brucella melitensis in the cerebrospinal fluid was confirmed with PCR assay. We believe that neurobrucellosis should be included in the differential diagnosis when headaches persist following brucellosis. In addition, we suggest that when cerebrospinal fluid culture is negative, PCR may prove to be an optimal alternative tool for an immediate and accurate diagnosis.

\section{Introduction}

Brucellosis is an endemic zoonotic disease, common in certain areas such as the Mediterranean basin, the Middle East, or South America [1, 2]. During the last decades, globalization and technology made worldwide traveling easy. These rather recent population shifts introduced a new era in the epidemic profile of many infectious diseases, changing their distribution, and making them reappear in places where they were previously considered eradicated. For example in 1991, the United Kingdom was declared brucellosis-free yet 148 new cases were reported during the period 2001-2006 amongst them three affecting the central nervous system, otherwise called neurobrucellosis [3]. There are many discrepancies in the diagnostic criteria of neurobrucellosis, and the literature is mainly restricted to case reports and short series [2].

\section{Case Presentation}

A 4-year-old boy was admitted to our institution because of vomiting and persistent headaches. One month before admission, he had been admitted to another hospital with fever and difficulty walking. Brucellosis is endemic in the region, and Wright agglutination test is routinely performed among other examinations for the differential diagnosis of fever combined with limb dysfunction. The test was positive and the patient was treated by intramuscular gentamicin, oral doxycycline, and rifampicin. Poor compliance to oral antibiotics secondary to vomiting resulted in readmission to our hospital. CBC showed lymphocytic pleocytosis (WBC count $7.400 / \mathrm{mL}$, polymorphonuclear cells $42 \%$, and lymphocytes $48 \%$ ). Erythrocyte sedimentation rate, liver and renal function tests were normal. The Wright agglutination test for brucellosis in the serum was positive at a titer of $1: 320$. Fundoscopy showed obliteration of the left optic disc margin. An antibiotic regimen of cotrimoxazole and rifampicin was initiated.

During the first week of admission, headaches worsened. Serial fundoscopy showed frank left side papilledema. Ocular movements revealed left abducens palsy and horizontal diplopia. Papillary light reflexes were bilateral normal and no afferent papillary defect was present. Meningeal or other focal neurological features were absent. Brain magnetic 
TABLE 1: Important presenting symptoms, investigation procedures, and treatment features, comparing to other cases of neurobrucellosis presented with intracranial hypertension.

\begin{tabular}{|c|c|c|c|c|}
\hline & Sinopidis et al. & Özisik et al. [4] & Yilmaz et al. [5] & Tanir et al. [6] \\
\hline $\begin{array}{l}\text { Patient gender } \\
\text { and age }\end{array}$ & $\begin{array}{l}\text { Male } \\
4 \text { years }\end{array}$ & $\begin{array}{l}\text { Female } \\
38 \text { years }\end{array}$ & $\begin{array}{l}\text { Female } \\
15 \text { years }\end{array}$ & $\begin{array}{l}\text { Female } \\
13 \text { years }\end{array}$ \\
\hline $\begin{array}{l}\text { Clinical } \\
\text { presentation }\end{array}$ & $\begin{array}{c}\text { Vomiting } \\
\text { Headache } \\
\text { Papilledema } \\
\text { Horizontal diplopia }\end{array}$ & $\begin{array}{c}\text { Vomiting } \\
\text { Diplopia } \\
\text { Headache } \\
\text { Arthralgia } \\
\text { Bilateral papilla stasis }\end{array}$ & $\begin{array}{c}\text { Vomiting } \\
\text { Headache } \\
\text { Papilledema } \\
\text { Horizontal Diplopia }\end{array}$ & $\begin{array}{l}\text { Intracranial hypertension, } \\
\text { initially diagnosed as } \\
\text { meningoencephalitis, no } \\
\text { specific details given }\end{array}$ \\
\hline Brain MRI & Normal & Normal & Normal & Normal \\
\hline $\begin{array}{l}\text { Blood } \\
\text { examinations }\end{array}$ & $\begin{array}{c}\text { WBC count } 7.400 / \mathrm{mL} \\
\text { Neutrophils } 42 \% \\
\text { Lymphocytes } 48 \% \\
\text { Normal CRP and ESR } \\
\text { Wright agglutination test } \\
\text { 1: } 320\end{array}$ & $\begin{array}{l}\text { WBC count } 5.500 / \mathrm{mm}^{3} \\
\text { Lymphocytes } 64 \% \text {, } \\
\text { Neutrophils } 24 \% \\
\text { Monocytes } 12 \% \\
\text { ESR } 20 \mathrm{~mm} / \mathrm{h} \\
\text { Brucella serum test } 1 / 80\end{array}$ & $\begin{array}{c}\text { Normal blood count } \\
\text { Normal CRP } \\
\text { ESR } 4 \mathrm{~mm} / \mathrm{h} \\
\text { Positive Rose Bengal test } \\
\text { Wright agglutination test } \\
\text { 1: } 160\end{array}$ & $\begin{array}{l}\text { Serum agglutination test } \\
\text { 1: } 320 \\
\text { 2-Mercaptoethanol test } \\
1: 160\end{array}$ \\
\hline $\begin{array}{l}\text { Opening } \\
\text { intracranial } \\
\text { pressure }\end{array}$ & $48 \mathrm{mmHg}$ & $300 \mathrm{~mm} \mathrm{H}_{2} \mathrm{O}$ & $340 \mathrm{~mm} \mathrm{H}_{2} \mathrm{O}$ & $\begin{array}{l}\text { Increased, measurement } \\
\text { not specified }\end{array}$ \\
\hline CSF & $\begin{array}{c}162 \text { cells/mL } \\
\text { Neutrophils } 86 \% \\
\text { Monocytes } 14 \% \\
\text { Glucose } 32 \mathrm{mg} / \mathrm{dL} \\
\text { Protein } 60 \mathrm{mg} / \mathrm{dL} \\
\text { Negative culture } \\
\text { Positive PCR reaction }\end{array}$ & $\begin{array}{c}\text { Lymphocytes } 80 / \mathrm{mm}^{3} \\
\text { Protein } 0.20 \mathrm{mg} / \mathrm{L} \\
\text { Glucose } 0.53 \mathrm{mg} / \mathrm{L} \\
\text { Normal Gram and } \\
\text { methylene blue stains } \\
\text { Negative ordinary culture } \\
\text { Positive BACTEC system } \\
\text { culture }\end{array}$ & $\begin{array}{c}10 \text { cells } / \mu \mathrm{L} \\
\text { Glucose } 58 \mathrm{mg} / \mathrm{dL} \\
\text { Protein } 48 \mathrm{mg} / \mathrm{dL} \\
\text { Positive Rose Bengal test } \\
\text { Wright agglutination test } \\
1: 80 \\
\text { Positive culture }\end{array}$ & $\begin{array}{c}500 \text { cells } / \mathrm{mm}^{3} \\
\text { Lymphocytes } 80 \% \\
\text { Neutrophils } 20 \% \\
\text { Glucose } 47 \mathrm{mg} / \mathrm{dL} \\
\text { Protein } 58 \mathrm{mg} / \mathrm{dL} \\
\text { Serum agglutination test } \\
1 / 10 \\
\text { Negative culture }\end{array}$ \\
\hline Treatment & $\begin{array}{l}\text { Rifampicin, cotrimoxazole, } \\
\text { ciprofloxacin added later }\end{array}$ & $\begin{array}{l}\text { Doxycyclin, rifampicin, and } \\
\text { trimethoprime with } \\
\text { sulfamethoxazole }\end{array}$ & $\begin{array}{l}\text { Streptomycin, doxycyclin, } \\
\text { and rifampicin }\end{array}$ & $\begin{array}{l}\text { Doxycyclin, rifampicin, } \\
\text { gentamicin }\end{array}$ \\
\hline
\end{tabular}

resonance imaging (MRI) was normal, and bone scanning did not reveal any focal involvement.

Lumbar puncture revealed clear cerebrospinal fluid (CSF) with high opening pressure $(48 \mathrm{mmHg})$, and white blood cell count of 162 cells/mL (neutrophils 86\%, monocytes $14 \%$ ), glucose $32 \mathrm{mg} / \mathrm{dL}$, and protein $60 \mathrm{mg} / \mathrm{dL}$. CSF cultures were negative, but CSF polymerase chain reaction (PCR) examination was positive for brucellosis. Hence, the diagnosis of neurobrucellosis associated with intracranial hypertension was confirmed. Ciprofloxacin was added to the initial antibiotic regimen, and acetazolamide was administrated for intracranial hypertension.

Repeat fundoscopy ten days later showed improvement of the left-sided papilledema. A second measurement of intracranial pressure two weeks later showed an improvement at $33 \mathrm{mmHg}$, which was further reduced to $26 \mathrm{mmHg}$ after removal of $10 \mathrm{~mL}$ of CSF fluid. Headache regressed gradually. One month after admission, fundoscopy showed residual blurring of the temporal margin of the left optic disc. Ciprofloxacin was substituted by moxifloxacine. Acetazolamide was well tolerated and was gradually withdrawn, based on clinical improvement and normal opening pressure measurement on the last lumbar puncture which was performed before discharge.

After two months in the hospital, the patient was discharged on a regimen of cotrimoxazole, rifampicin, and moxifloxacine for one month, followed by a period of four months with cotrimoxazole and rifampicin, with no residual deficits.

\section{Discussion}

Brucellosis is an endemic infectious disease of animals (zoonosis) that is transmittable to humans through the consumption of their products, after exposure to their blood, or through direct contact [1]. The symptoms of the infection are nonspecific, and often subtle [1]. Diagnosis is suspected if there is a high index of suspicion, due to history of animal product exposure or travelling [1]. A definitive diagnosis is obtained by isolation of Brucella species from the blood or other tissues, or by demonstration of high titers of specific antibodies in the serum [1].

Neurobrucellosis ranges from 1.7 to $10 \%$ of Brucella infections $[4,5]$. Incidence in the pediatric age group is much lower, with an average rate of $0.8 \%[4,5]$. The most common clinical presentation is subacute and chronic meningoencephalitis [3, 7]. Myelitis, radiculoneuritis, brain and epidural abscess, and meningovascular syndromes are other inflammatory processes encountered [2]. MRI examination may present with normal findings, inflammatory changes, or white matter and vascular changes $[8,9]$. 
Leukocyte pleocytosis and high protein levels are seen in the cerebrospinal fluid. Positive cultures from the serum and other specimens are observed in less than $50 \%[7,10]$. In a recent study of a large number of neurobrucellosis cases, only $28 \%$ of blood cultures and $14 \%$ of CSF cultures were positive for Brucella [2]. As Brucella is a slowly growing bacterium, initial cultures in earlier phases of the disease may be negative [3]. The detection of neurobrucellosis is often based on the neurological picture, evidenced by systemic Brucella infection, and the presence of inflammatory alteration in the CSF [2]. PCR assay of the cerebral fluid for Brucella is a novel evolving and promising diagnostic method [10]. PCR proved to be very helpful in the diagnosis of neurobrucellosis in our case, since CSF cultures were negative.

Involvement of one or more cranial nerves has been noted in more than $50 \%$ of neurobrucellosis cases $[2,11]$. The main mechanism is basal meningitis affecting the course of the nerves. Other mechanisms include pseudotumor cerebri, vasculitis, and tetracycline side effects [2]. The vestibulocochlear nerve is the most frequently involved [2]. The long intracranial course of the abducens nerve makes it also susceptible to insults like microvascular infarction or direct compression [2]. One case of isolated abducens nerve palsy with borderline intracranial pressure in a young adult female patient has also been reported [11]. Facial, optic, and oculomotor nerves are other reported cranial nerves to be affected [2]. In a pooled analysis of 35 publications on neurobrucellosis in the general population, only one out of $187(0.5 \%)$ patients presented with intracranial hypertension [2].

Papilledema is a common manifestation of intracranial hypertension. In our case this finding was unilateral. Unilateral papilledema is reported in cases of idiopathic intracranial hypertension [12]. The mechanism is unknown. A recent study suggests compartmentation of the subarachnoid space of the optic nerve [13]. Presentation of neurobrucellosis with increased intracranial pressure in children and adolescents is very uncommon (Table 1) $[4-6,14]$. In a retrospective study of over 90 children with brucellosis, Tanir et al. reported a 13-year-old female patient with neurobrucellosis, increased intracranial pressure, negative CSF culture, and normal cranial MRI [6]. Yilmaz et al. reported recently a 15year-old girl with headache, vomiting, diplopia with inward deviation of the left eye, and papilledema. Cranial MRI was normal. Intracranial hypertension was confirmed, and Brucella melitensis grew on CSF culture [5].

Our patient presented with intracranial hypertension, headache, diplopia, and papilledema, and normal brainMRI. Brucella melitensis in the CSF was confirmed with PCRassay. He is the youngest reported case with neurobrucellosis presenting the association of intracranial hypertension, diplopia, and normal cranial MRI. We suggest that neurobrucellosis should be included in the differential diagnosis when headaches persist following Brucellosis. In addition, we also suggest that when CSF culture is negative, PCR may prove to be an optimal alternative tool for an immediate and accurate diagnosis [10].

\section{Conflict of Interests}

The authors declare no conflict of interests.

\section{References}

[1] E. J. Young, "Brucellosis," in Bacterial Infections of Humans, A. S. Evans and P. S. Brachman, Eds., pp. 177-188, Springer Science and Business Media, LLC, 2009.

[2] H. C. Gul, H. Erdem, and S. Bek, "Overview of neurobrucellosis: a pooled analysis of 187 cases," International Journal of Infectious Diseases, vol. 13, no. 6, pp. e339-e343, 2009.

[3] R. P. D. Cooke and N. J. Beeching, "Neurobrucellosis in the UK," Journal of Infection, vol. 58, no. 1, pp. 88-89, 2009.

[4] H. I. Özisik, Y. Ersoy, M. Refik Tevfik, S. Kizkin, and C. Özcan, "Isolated intracranial hypertension: a rare presentation of neurobrucellosis," Microbes and Infection, vol. 6, no. 9, pp. 861-863, 2004.

[5] S. Yilmaz, G. Serdaroglu, S. Gokben, and H. Tekgul, "A case of neurobrucellosis presenting with isolated intracranial hypertension," Journal of Child Neurology, vol. 26, no. 10, pp. 1316-1318, 2011.

[6] G. Tanir, S. B. Tufekci, and N. Tuygun, "Presentation, complications, and treatment outcome of brucellosis in Turkish children," Pediatrics International, vol. 51, no. 1, pp. 114-119, 2009.

[7] N. Ceran, R. Turkoglu, I. Erdem et al., "Neurobrucellosis: clinical, diagnostic, therapeutic features and outcome. Unusual clinical presentations in an endemic region," Brazilian Journal of Infectious Diseases, vol. 15, no. 1, pp. 52-59, 2011.

[8] O. Kizikilic and C. Calli, "Neurobrucellosis," Neuroimaging Clinics of North America, vol. 21, no. 4, pp. 927-937, 2011.

[9] M. W. Al-Sous, S. Bohlega, M. Z. Al-Kawi, J. Alwatban, and D. R. McLean, "Neurobrucellosis: clinical and neuroimaging correlation," American Journal of Neuroradiology, vol. 25, no. 3, pp. 395-401, 2004.

[10] J. D. Colmenero, M. I. Queipo-Ortuño, J. M. Reguera, G. Baeza, J. A. Salazar, and P. Morata, "Real time polymerase chain reaction: a new powerful tool for the diagnosis of neurobrucellosis," Journal of Neurology, Neurosurgery and Psychiatry, vol. 76, no. 7, pp. 1025-1027, 2005.

[11] M. Yilmaz, R. Ozaras, A. Mert, R. Ozturk, and F. Tabak, "Abducent nerve palsy during treatment of brucellosis," Clinical Neurology and Neurosurgery, vol. 105, no. 3, pp. 218220, 2003.

[12] P. R. Wattamwar, N. N. Baheti, and A. Radhakrishnan, "Idiopathic intracranial hypertension presenting as unilateral papilledema," Neurology India, vol. 58, no. 5, pp. 818-819, 2010.

[13] H. E. Killer, G. P. Jaggi, J. Flammer, N. R. Miller, A. R. Huber, and A. Mironov, "Cerebrospinal fluid dynamics between the intracranial and the subarachnoid space of the optic nerve. Is it always bidirectional?" Brain, vol. 130, no. 2, pp. 514-520, 2007.

[14] O. Tekeli, S. Tomac, E. Gursel, and H. Hasiripi, "Divergence paralysis and intracranial hypertension due to neurobrucellosis. A case report," Binocular Vision and Strabismus Quarterly, vol. 14, no. 2, pp. 117-118, 1999. 


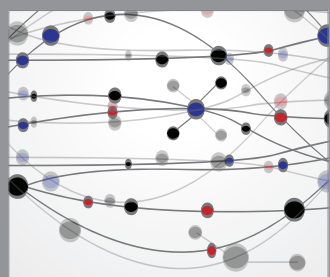

The Scientific World Journal
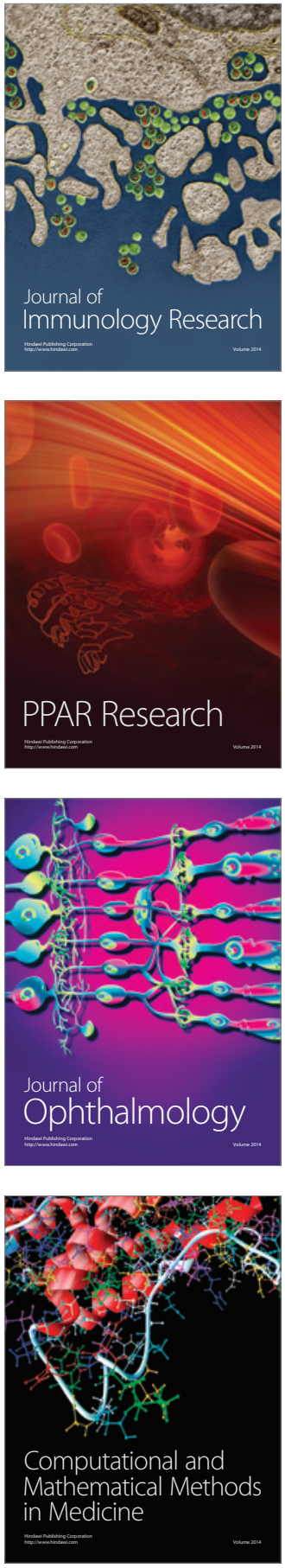

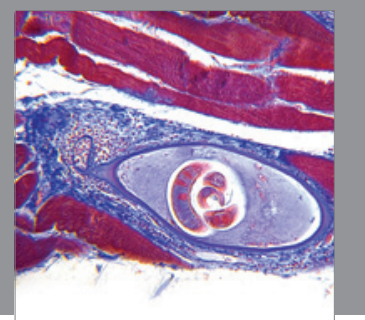

Gastroenterology

Research and Practice
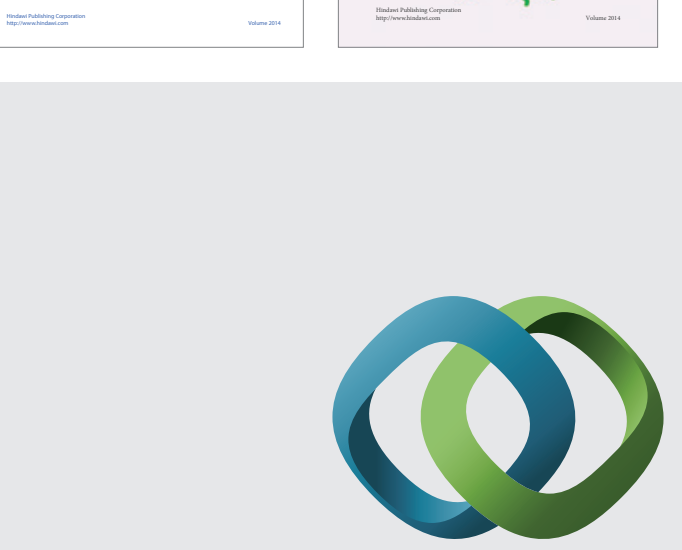

\section{Hindawi}

Submit your manuscripts at

http://www.hindawi.com
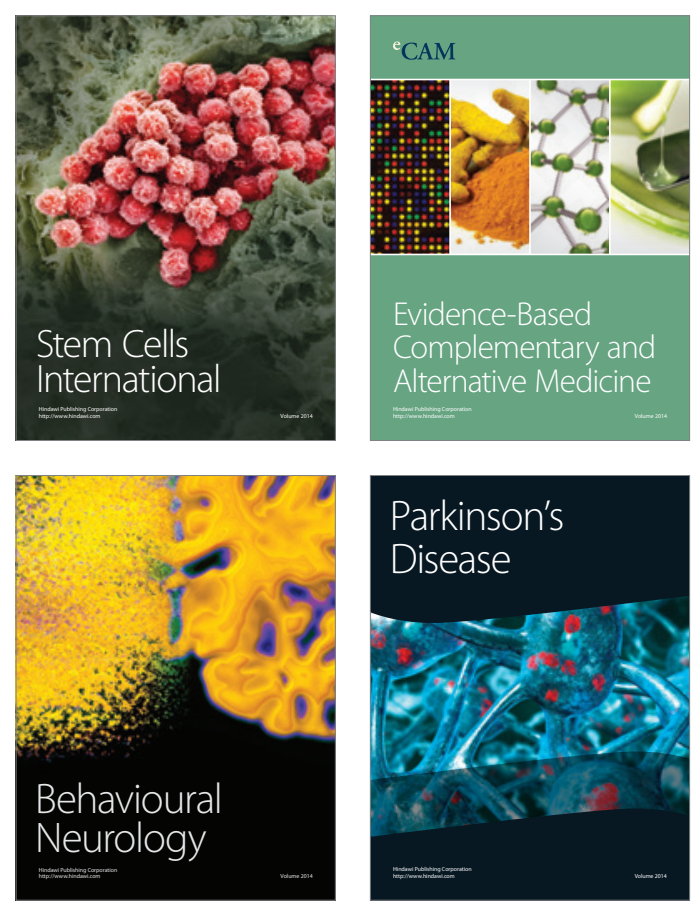

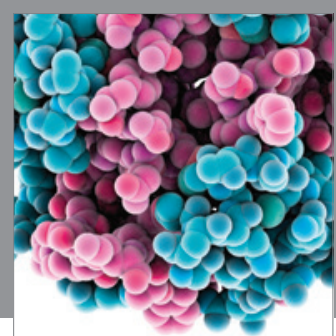

Journal of
Diabetes Research

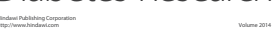

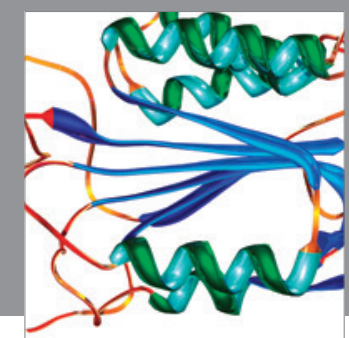

Disease Markers
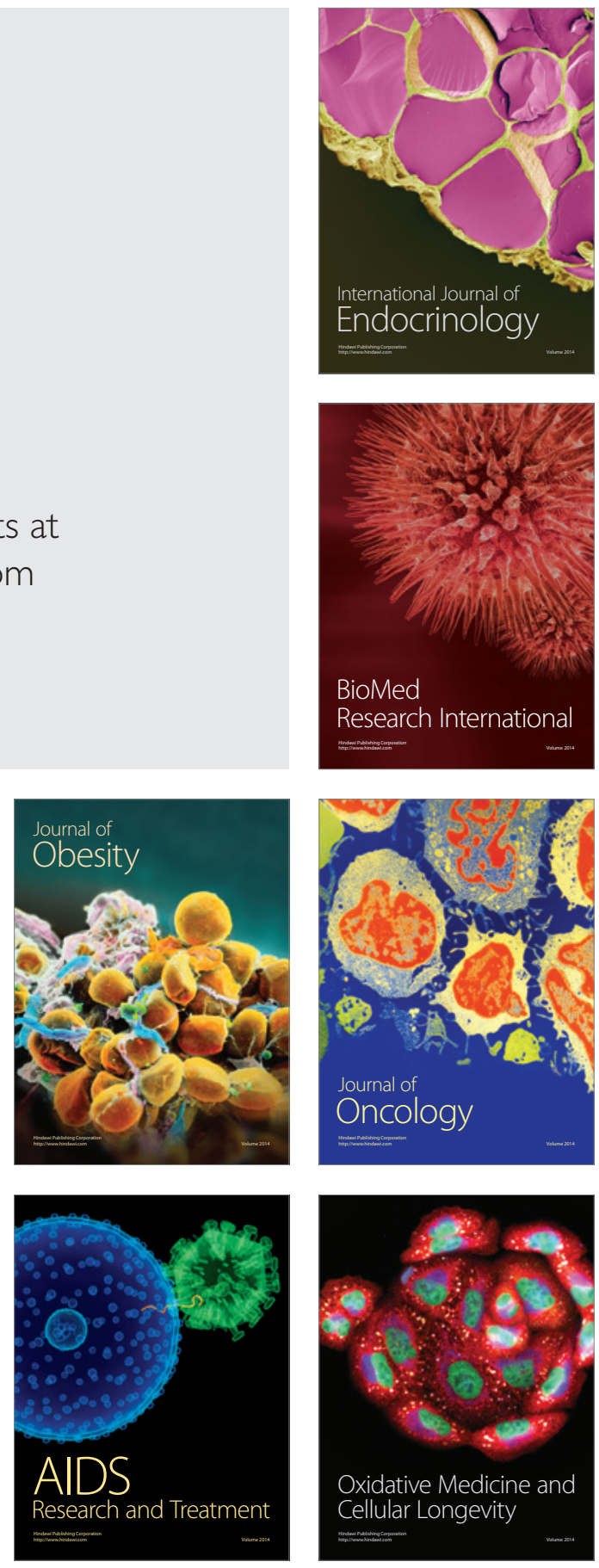